\title{
E-Culture: The Strategy of Character Development Based on Music Lullabies Songs ( Etnis Batak Toba, Mandailing Natal Provinsi Sumatera Utara)
}

\author{
Irawaty A.Kahar ${ }^{1}$, Matha $^{2}$, Dirmasyah ${ }^{3}$, Zaslina $^{4}$ \\ \{ir_kahar@yahoo.com\} \\ 1,3,4 Ilmu Perpustakaan dan Informasi, FIB, Universitas Sumatera Utara, Padang Bulan \\ 2, Sastra Inggris, FIB, Universitas Sumatera Utara, Padang Bulam. 20155, Indonesia
}

\begin{abstract}
This study aims to preserve the oral tradition of lullabies songs based on local wisdom and music media. The lyrics of lullabi, songs contain local wisdom, that can be used as the children's character development. The strain of its music sounds would build the emotion and positive characters to child in fact the lullabies songs of ethnicities in North Sumatra are not known by the current generation. This condition is a threat to the nation's culture, the value of local wisdom is on the verge of extinction. Also the tenager phase, will experience the gradation of positive character. As a solution, E-culture must be implemented in order to preserves of lullabies songs with the development of ICT, includes (1) management (inventory and identify) of lullabies songs of North Sumatra ethnic, (2) documentation (recording of oral traditional lullabies song, rearranged and digitalized. The study uses qualitative methods, using content analysis through function and meaning. The result showed, that it has been inventoried 13 Lullabies with 6 classifications of local wisdom value. All the lullabies songs, are with soft and calm rhythm. So it can be relied on in forming positive character of the children.
\end{abstract}

Keywords: Oral Tradition Lullabies, E-Culture, Music, Child Character

\section{Introduction}

Oral tradition of lullabies songs is a cultural strength in forming the national identity and character that must be preserved. Dahliani [1] "local wisdom is a collection of knowledge, practices and beliefs that develop through an adaptive process (adjustment) which is passed down from generation to generation through culture, related to the relationship between living things (including humans) and the surrounding environment". According to Sibarani [2], the types of local wisdom are (1) for peace: consisting of courtesy, honesty, social loyalty, harmony, and changes in conversation. commitment, positive thoughts, and gratitude. (2) for prosperity which consists of hard work, discipline, education, health, mutual cooperation, preservation and cultural creativity, and care for the environment. Lyrics of lullabies songs are full of local wisdom, and the delivery can be in the form of a proverb, poetry, or rhymes. Neno Lestari [3] explains "Lullabies songs is accompanied by a song containing advice, and prayer, which is a parent's habit when a child is crying and going to bed". [4]"Lullaby is a tradition 
sung all over the World in order to send children to sleep". The due tradition has very positive and constructive effects on children. Noor Adeham. [5] "song lyrics put children to rhythmic sleep softly, calmly and repeatedly, their words are affectionate because they contain persuasion so that the child wants to close their eyes"

To sustain the values of local wisdom, still exist, Information and Communication Technology (ICT) will be used. This was discussed by Nasution [6] "information and Comunication Technology (ICT), is not only important for the wafare of the communication, but olso more impotantly to establish a tie between different generation". Acording to Europen Council of Ministers [7] that "Digitalization and oneline accessibility and the most important preserving scientific and culture heritage and to inspire the creation of new content and to encourage the emergence of new oneline services".

Sitokdana [8] that "e_culture is a combination of Communication Information Technology with traditional culture "oneline services". Acordance to Mulyanto [9], "One strategy for preservation and development of culture that can be done is to use Information Technology such as website". accordance with the era of globalization, music of lullabies songs, must be preservation through e-culture. Several studies have shown that lullabies songs will be more effective if it is delivered through the rhythm of music. Jimenez [10] "Music Therapy also has an impact on implementation, promotion, prevention and rehabilitation of the physical, mental, emotional and social health of people, groups and communities, including its intervention with babies and their mothers". Besides, the rhythm of music affects the emotion and the children's character development. Lin Zheng [11] explains, "to improve children's emotional quotient through music, to develop a good character, emotional management and the ability to communicate with people". Based on the research above, it can be concluded that the delivery of singing accompanied by music give such positive impact towards the development of children's emotion, mental, physical and character. Ana Rosmiati [12] states that "Character building is needed to instill education, personality, and morals for early childhood". To form the character of a good child, it takes educative song lyrics such as the lyrics of lullabies songs Batak Toba, and Mandailing Natal.

\section{Research Method}

The study uses qualitative methods, using content analysis through function and meaning. The application of e-culture requires a strategy with stages, namely (1) management including inventoring 13 song of of Batak Toba and Mandailing Natal ethnic. Then identifying the local wisdom values of lullabies song, there are (1) love say. (2) education, (3) The values of serving the parents, (4) religion, (5) Hard work), (6) advises. For to documentation (strategy step 2) was to record of lullabies songs of native perpetrators in each ethnicity (Batak Toba and Mandailing Natal). The song was rearranged to the accompaniment of music. Not all the songs that were inventorized had been recorded, but the songs that had been recorded have represented the lullabies songs of each ethnicity, on the object of research. 


\section{Results And Discussion}

\subsection{Strategi $E$-Culture Step 1: Management}

$\backslash$ One of tradition is lullabies songs, performed by the mother, grandmother of the child. But the fact shows that the lullabies song is no longer heard by the current generation. To maintain the child swinging song as a local culture we must implement e-culture, which is a combination of information and communication technology with traditional culture. The application of e-culture requires a strategy with stages, namely (1) management including inventoring 13 song of of Batak Toba and Mandailing Natal ethnic. Then identifying the local wisdom values of lullabies song, there are (1) love say. (2) education, (3) The values of serving the parents, (4) religion, (5) Hard work), (6) advises.

Table 1: Inventorying and Indentiying of Local Wisdom the Lullabies Songs Batak Toba (Balige).

\begin{tabular}{|c|c|c|c|}
\hline & $\begin{array}{l}\text { Mengayun Anak (Balige) "Modom Ma } \\
\text { Damang Usok and Dideng-dideng", in } \\
\text { language Batak Toba Samosir. }\end{array}$ & English Ingguage & Local Wisdom \\
\hline 1 & $\begin{array}{l}\text { Modom Ma Damang Usok. } \\
\text { Modom ma damang unsok, Modom ma } \\
\text { damang unsok. } \\
\text { Modom ma damang unsok, ha sian ni ina } \\
\text { mu. } \\
\text { Dison don ma au da usok man jaga ho. } \\
\text { Da Modom ma damang unsok man jaga } \\
\text { ho. } \\
\text { Tanpuk ni pusu pu sung ku do damang da } \\
\text { nsok. } \\
\text { Urat ni ate atenghu do damang da unsok. } \\
\text { Da modom ma da mang unsok hasianku. } \\
\text { Da Modom ma damang unsokoton } \\
\text { dingku. }\end{array}$ & $\begin{array}{l}\text { English: } \\
\text { Sleep tight my baby boy, } \\
\text { Sleep tight my son. } \\
\text { Sleep tight my baby, my } \\
\text { loving baby boy } \\
\text { I'm here looking after you } \\
\text { Sleep tight my baby boy, } \\
\text { Sleep tight } \\
\text { You are the apple my eges } \\
\text { You are my Venus my baby } \\
\text { boy } \\
\text { Sleep tight my loving baby } \\
\text { boy } \\
\text { Sleep tight my baby boy my } \\
\text { soul }\end{array}$ & $\begin{array}{l}\text { the values of love } \\
\text { and affection }\end{array}$ \\
\hline 2 & $\begin{array}{l}\text { Simbur ma godang ma ho, simbur ma } \\
\text { godang } \\
\text { Asa adong muse ho simbur ma godang. } \\
\text { Ai anggo Amanta, tongso di ingot beho. } \\
\text { Nunga tung lupa di ho, modom ma ho. } \\
\text { Dang hu perbaga be anngo Amanta de } \\
\text { Unsok. } \\
\text { Turi-turian do pansar lana de Unsok. } \\
\text { Ai di Perjudian do I so mulak so ro. } \\
\text { Nunga tung lupa di ho modom ma ho. }\end{array}$ & $\begin{array}{l}\text { English: } \\
\text { Grow up soon, you Grow up } \\
\text { soon } \\
\text { So I can laen on you } \\
\text { Your father does not pay } \\
\text { attantion on you anymore } \\
\text { He has forgotten you, Sleep } \\
\text { tight } \\
\text { I doesn't eare Your father } \\
\text { anymore } \\
\text { It istri only a story I'm } \\
\text { looking for him } \\
\text { Your father is at the gamble } \\
\text { place } \\
\text { He does not Come any more } \\
\text { He does not care about you } \\
\text { any more Sleep tight }\end{array}$ & $\begin{array}{l}\text { The values of } \\
\text { serving the parents. }\end{array}$ \\
\hline
\end{tabular}




\begin{tabular}{|c|c|c|c|}
\hline & $\begin{array}{l}\text { Mengayun Anak (Balige) "Modom Ma } \\
\text { Damang Usok and Dideng-dideng", in } \\
\text { language Batak Toba Samosir. }\end{array}$ & English Ingguage & Local Wisdom \\
\hline 3 & $\begin{array}{l}\text { Laho pe ahu da sogot marbata tu balian } \\
\text { Asa adong tuduhanta lao parbodarian mu. } \\
\text { Naborat sude na dokdok hu hongkap d0 } \\
\text { ho. } \\
\text { Da asal ma damang mokmok pagos pe } \\
\text { taho. } \\
\text { Perjudi langis, pemabuk Amanta da Ucok. } \\
\text { Ai nunga tugade sude sude soada di ho } \\
\text { Da sabar do au da Unsok, mangolu ma } \\
\text { ho. }\end{array}$ & $\begin{array}{l}\text { English: } \\
\text { In the morning I go to the } \\
\text { rice field } \\
\text { To get something for us to } \\
\text { eat } \\
\text { It is really a heavy, but I } \\
\text { still love you } \\
\text { I don't care as long as you } \\
\text { are healthy } \\
\text { Your father is gambler and } \\
\text { a drunk Hard } \\
\text { If Your father is defeaded, } \\
\text { he is getting angry } \\
\text { Be fortiul my baby boy } \\
\text { Sleep alive }\end{array}$ & hard work \\
\hline 4 & $\begin{array}{l}\text { Dideng-dideng au } \\
\text { Molo Molo I ingit I sude, Loja ni dainang } \\
\quad \mathrm{i} \\
\text { Marmudu au sian na met-met tuna balga } \\
\text { Diabing au diompa au, asa sonang } \\
\quad \text { modom au } \\
\text { Dideng-dideng didok muse, O hasian. }\end{array}$ & $\begin{array}{l}\text { English: } \\
\text { Swing. Swing } \\
\text { If I remember everything, } \\
\text { how tired my mom } \\
\text { Looking after me from the } \\
\text { craddle up to now i am } \\
\text { adult } \\
\text { I have been halding, put on } \\
\text { her to make me Sleep tight } \\
\text { Swing swing }\end{array}$ & the values of love \\
\hline
\end{tabular}

Tabel 2. Iventoring and Identifying of lullabies Songs and Local Wisdom Batak Toba (Simalungun)

\begin{tabular}{|c|c|c|c|}
\hline & $\begin{array}{l}\text { Mengayun anak Simalungun in } \\
\text { language Batak Toba. }\end{array}$ & $\begin{array}{c}\text { Version } \\
\text { English langguage } \\
\end{array}$ & Local Wisdom \\
\hline 1 & $\begin{array}{l}\text { Urdo-urdo } \\
\text { Urmalo dayok, urmalo dayok } \\
\text { Ulang tangis ringisan, si anggi te } \\
\text { e... e. } \\
\text { Namodom ham na modom, si } \\
\text { anakku e..e, Modom na ham na } \\
\text { modom Si Boruku e...e. } \\
\text { Ase padas marbakgal Si anakku } \\
\text { e...e }\end{array}$ & $\begin{array}{l}\text { English: } \\
\text { Swing swing } \\
\text { Come here Chick, Come } \\
\text { here Chick } \\
\text { Don't cry, rabbing } \\
\text { Oh my son } \\
\text { Sleep tight my son } \\
\text { Go Sleep my son } \\
\text { Grow up my son }\end{array}$ & the values of love \\
\hline 2 & $\begin{array}{l}\text { Urmalo dayok, urmalo dayok } \\
\text { Podas-podas marganjang Si } \\
\text { Boruku e...e } \\
\text { Marganjang nasa hotang Si }\end{array}$ & $\begin{array}{l}\text { English: } \\
\text { Chick Come here, came here } \\
\text { Chick } \\
\text { Grow tall soon my son } \\
\text { Tall as rattan my son } \\
\end{array}$ & the advice values \\
\hline
\end{tabular}




\begin{tabular}{|c|c|c|c|}
\hline & $\begin{array}{l}\text { Mengayun anak Simalungun in } \\
\text { language Batak Toba. }\end{array}$ & $\begin{array}{c}\text { Version } \\
\text { English langguage }\end{array}$ & Local Wisdom \\
\hline & $\begin{array}{l}\text { Boruku } \\
\text { Marganjang peg an nikku Si } \\
\text { Anggitta si anakku } \\
\text { Ulang sundol hu langit Si Boruku } \\
\text { e...e } \\
\text { Urmalo dayok, urmalo dayok }\end{array}$ & $\begin{array}{l}\text { Tall, I Medan my son } \\
\text { Don't Grow tall up to the } \\
\text { Sleep my son } \\
\text { Here Chick, Come here }\end{array}$ & \\
\hline 3 & $\begin{array}{l}\text { Podas-podas marbakgal Si } \\
\text { anakku e...e } \\
\text { Marbakgal nasa hobon Si anakku } \\
\text { Ulang sundol hu labah si anakku } \\
\text { e...e } \\
\text { Urmalo dayok, urmalo dayok }\end{array}$ & $\begin{array}{l}\text { English: } \\
\text { Grow up my baby boy } \\
\text { Grow up, big like the barn for } \\
\text { rice } \\
\text { Getting Blogger but you must } \\
\text { fit the door } \\
\text { Here Chick, Come here } \\
\text { Chick }\end{array}$ & education \\
\hline
\end{tabular}

Tabel 3. Iventoring and Identifying of Lullabies Songs and Local Wisdom Mandailing Natal

\begin{tabular}{|c|c|c|c|}
\hline & $\begin{array}{l}\text { Mengayun Anak "Urdo- } \\
\text { urdo" in Language Batak } \\
\text { Toba Samosir (Simalungun). }\end{array}$ & $\begin{array}{c}\text { Version } \\
\text { English langguage }\end{array}$ & Local Wisdom values \\
\hline 1 & $\begin{array}{l}\text { Modom...modom maho } \\
\text { Amang da anak ku } \\
\text { Modom makulak ulak } \\
\text { Ho amang di anggunan mi } \\
\text { Maho di anggunan } \\
\text { odom u..u..u anak ku } \\
\text { haholongan. }\end{array}$ & $\begin{array}{l}\text { English: } \\
\text { Go to Sleep } \\
\text { My loving son } \\
\text { Go to Sleep } \\
\text { You are In Your craddle } \\
\text { So Sleep my loving boy }\end{array}$ & the values of love \\
\hline 2 & $\begin{array}{l}\text { We wawe Sipulut di Angkola } \\
\text { Magodang ma ho amang } \\
\text { Aso kele Sikola } \\
\text { Indu inda don urat nisi barebe } \\
\text { Anggo dung saulakon } \\
\text { Mambuat Boru napade. }\end{array}$ & $\begin{array}{l}\text { English: } \\
\text { Pulut rice at angkola } \\
\text { Getting big my son } \\
\text { So you can go to school } \\
\text { When you are mat } \\
\text { Find a smart girl }\end{array}$ & $\begin{array}{l}\text { The values that later } \\
\text { child persue.go to } \\
\text { school. }\end{array}$ \\
\hline
\end{tabular}




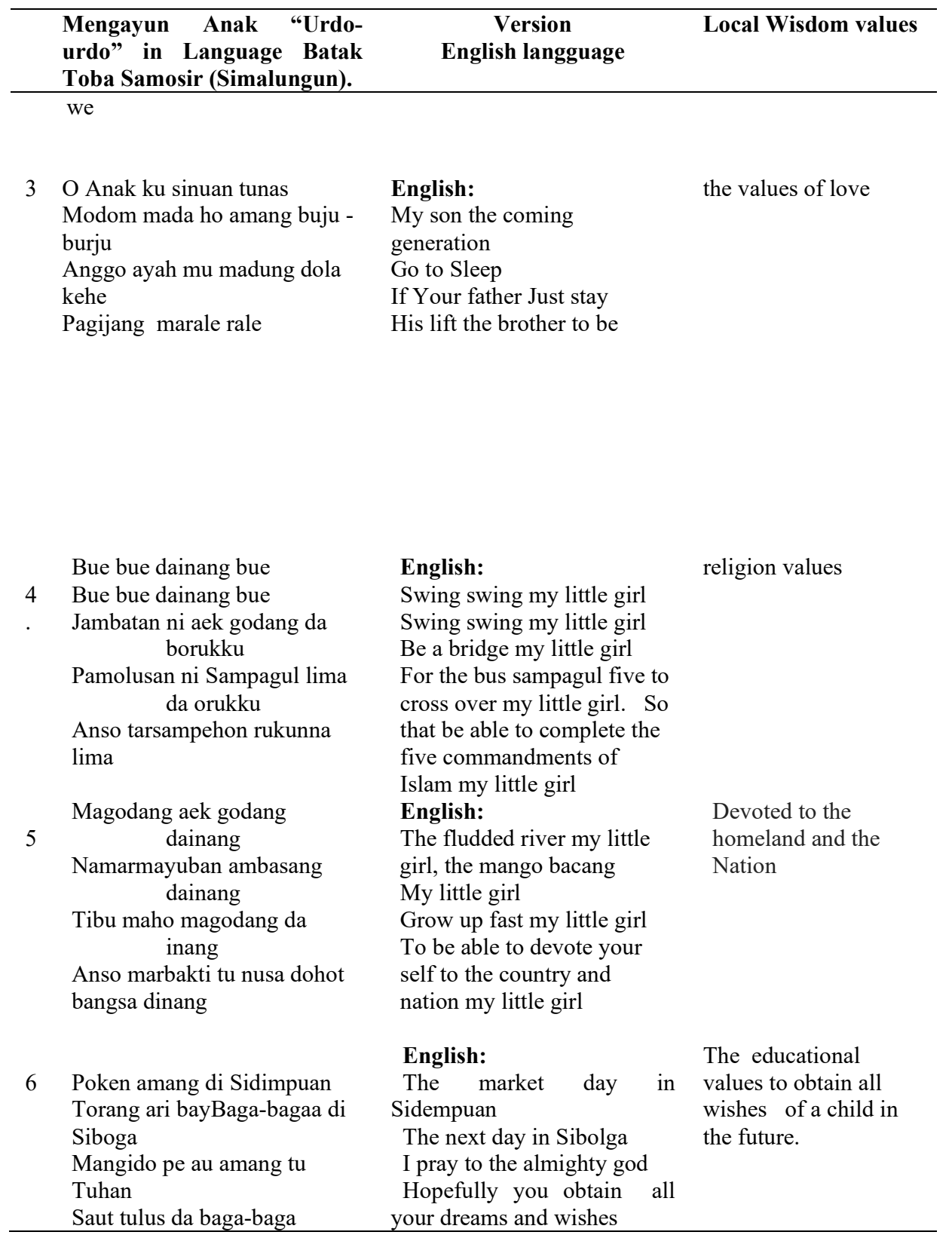

\subsection{E-Culture Strategy Step 2: Documentation}

For to documentation (strategy step 2) was to record of lullabies songs of native perpetrators in each ethnicity (Batak Toba and Mandailing Natal). The song was rearranged to the accompaniment of music. Not all the songs that were inventorized had been recorded, but the songs that had been recorded have represented the lullabies songs of each ethnicity, on the object of research. 
The recording is carried out through the stages of electronic recording. The equipment used are a recorder, a computer with sufficient RAM to run the Digital Audio Work (DAW) station program, instrument devices such as keyboards and flutes, and amplifiers. What was recorded was the voice of the singer, and musical instrument. Then the recording of lullabies song will be transferred to a CD / DVD, and the new version of the lullabies song is ready to be heard.

\subsection{Music Media to Developing the Character of the Children.}

The lullabies songs accompanied by music can affect children's emotions and psychology. Music can be used as a medium for character formation in early childhood, Ana Rosmiati states that "Character building is needed to instill education, personality, and morals in early childhood". Acordance to Swathi Swaminathan E. [13] that "research supports "folkpsychological ideas of a deep connection between music and emotion. Emotions influence what music listeners choose to hear, and music influences how they feel". In the process of forming music-based characters, trials have been carried out on 9 infants 0-3 years with proporsi, 3 people from Simalungun, 3 people from Balige and 3 people from Mandailing Natal proposive sampling). The trial was conducted in the morning at 10 and in the afternoon on the object of research in different days and times. First the mother puts the child in a swing and the mother starts swinging while singing. The song delivered was soft and calm. Researchers began to note how long the mother swung while singing until the child fell asleep. The results of the trial show that it takes the time needed to deliver the song until the child falls asleep on average 5-15 minutes. Acording to Belapurkar, [14], "The effect of music on mood is well known, and this effect also applies to children. Children can learn to regulate their feelings by listening to music to calm them down, give them energy, or help lift their moods". Patricia Fox Ransom say "Lyric are a tool just as music is, and when partnered with positive psychology, can make a positive impact on the hundreds and thousands of people who listen to music on a daily basis" [15] [16].

\section{Conclusion}

The result is: The lullabies song of Batak Toba and Mandailing Natal have been inventorized as much as 13 songs. with 6 classifications of local wisdom value the are (1) love saying. (2) education, (3) The values of serving the parents, (4) religion, (5) hard work), (6) advises. After recording the lullabies song will be transferred to CD or DVD. The new version of the lullabies song is ready to be heard. In general all of the lullabies songs, soft and calm rhythm. So it can be reled on in forming positive character of the child at the early age. Music plays roles in processing positive character.

\section{References}

[1] D. Dahliani, "Local wisdom in built environment in globalization era," in International Journal of Education and Research, vol. 3, no. 6, 2015, pp. 157-166.

[2] R. Sibarani, Pembentukan Karakter: Langkah-Langkah Berbasis Kearifan Lokal. Jakarta: Asosiasi Tradisi Lisan, 2015.

[3] N. L. D. N. E. Salam, "Etnografi Komunikasi Tradisi Mengayun Budak Pada Adat Melayu Siak Di Kota Dumai Provinsi Riau,” J. Chem. Inf. Model., vol. 3, no. 2, pp. 1689-1699, 2016. 
[4] H. Günes and N. Günes, "The Effects of Lullabies on Children," in International Journal of Business and Social Science, vol. 3, no. 7, 2012, pp. 316-321.

[5] N. Adeliani and J. M. Banjarmasin, "LAGU MENIDURKAN ANAK PADA MASYARAKAT BANJAR: Kajian Bentuk, Makna, dan Fungsi,” in journal AL-BANJARI, vol. 13, no. 2, 2014, pp. 265-283.

[6] M. K. M. Nasution, T. E. Nuradi, and R. Syah, "SumutSiana: A framework for applying ICT to preserve the cultural heritage of Sumatera Utara Indonesia," J. Telecommun. Electron. Comput. Eng., vol. 9, no. 2-4, pp. 123-128, 2017.

[7] "Europen Council of Ministers," 2014.

[8] Sitokdana, E Culture Merupakan Kombinasi Teknologi Informasi Komunikasi Dengan Budaya Tradisional. 2016.

[9] A. Mulyanto, M. Latief, and M. Rohandi, "Preservation and Development Strategies of Gorontalo' s Local Culture through Gorontalo Cultural Digital Repository Application," in Mudra, vol. 31, no. 3, 2016, pp. 285-294.

[10] S. Gutierrez-Jimenéz and V. Franco, "Music Therapy in Early Intervention - a Family Perspective," in Advances in Social Sciences Research Journal, vol. 5, no. 4, 2018, pp. 180-192.

[11] L. Zheng and C. Y. Bian, "Children's music education from the perspective of positive psychology,” Kuram ve Uygulamada Egit. Bilim., vol. 18, no. 6, pp. 3094-3100, 2018.

[12] A. Rosmiati, "Teknik Stimulasi dalam Pendidikan Karakter Anak Usia Dini melalui Lirik Lagu Dolanan,” Resital J. Seni Pertunjuk., vol. 15, no. 1, pp. 71-82, 2014.

[13] S. Swaminathan and E. G. Schellenberg, "Current emotion research in music psychology," Emot. Rev., vol. 7, no. 2, pp. 190-197, 2015.

[14] D. A. M. Belapurkar, "MUSIC FOR EMOTIONAL AND SOCIAL DEVELOPMENT OF CHILD," in cholarly Research Journal's, vol. SRJIS, Jan, no. : 04/03/2017, 2017, pp. 32-37.

[15] P. F. Ransom, "ScholarlyCommons Message in the Music: Do Lyrics Influence Well-Being?," 2015, pp. 1-43.

[16] K. Saddhono, "Integrating Culture in Indonesian Language Learning for Foreign Speakers at Indonesian Universities." J. of Lang. and Lit. vol. 6 no.2 pp. 349-353, 2015 